Czytelnik, który zgłębi pracę Miriam S. Taylor, ma okazję zapoznać się $\mathrm{z}$ umiejętnie przeprowadzoną krytyką dominującego paradygmatu badawczego, zwanego „teorią konfliktu”. Należy przyznać, że zastrzeżenia poczynione przez autorkę skłaniają, aby o wiele ostrożniej spoglądać na dostępne nam źródła i to jest istotna zasługa tej pracy. Te z nich bowiem, które nie mają charakteru patrystycznego, w nikły sposób rozpraszają mrok spowijający wzajemne relacje chrześcijańsko-żydowskie, a wnioski, jakie się z nich wyciąga, mogą prowadzić na manowce. Pisma Ojców Kościoła zaś poświęcone były problemom natury teologicznej, choć trzeba przyznać, że niekiedy powstawały one pod wpływem bieżących wydarzeń (np. herezja Marcjona). (Autorka dodałaby jednak, że odzwierciedlały one ponadczasowe idee oraz odporne na ząb czasu „historycznie transmitowane symbole”). Dzieła Tertuliana czy Melitona były wobec tego nie tyle reakcją na otaczającą rzeczywistość, ile odzwierciedleniem świata wyobrażeń religijnych obecnych wewnątrz chrześcijańskiej gminy. Jednak ten antyjudaizm, choć będący odpowiedzią na wewnętrzne potrzeby, w jakiś sposób kształtował późniejsze poczynania cesarzy, mnichów, a może i pospólstwa. Szkoda więc, że autorka nie próbuje dać odpowiedzi co do zależności, jakie mogły zachodzić pomiędzy abstrakcyjnym antyjudaizmem Ojców Kościoła, a wrogimi wystąpieniami z czasów tryumfu chrześcijaństwa. Wydaje się, że byłoby słusznym zabiegiem, gdyby w analizowanych źródłach literackich dostrzegać zarówno wpływy „symbolicznego antyjudaizmu”, za którym opowiada się autorka oraz bieżącej sytuacji. Powstaje dzięki temu obraz pełniejszy i pozbawiony suchej jednostronności. W innym przypadku trudno pozbyć się wątpliwości, czy model wieloprzyczynowy, odwołujący się do „tu i teraz” nie został zastąpiony przez monolityczną strukturę, implikującą brak wzajemnych kontaktów co najmniej od czasów apostolskich.

Wojciech Bejda - Lublin

\title{
Jeffrey Paul LYON, Syriac Gospel Translations: A Comparison of the Lan- guage and Diatessaron Method used in the Old Syriac, the Diatessaron and the Peshitto, CSCO 548, Subsidia 88, Louvain 1994, ss. 235.
}

Książka J. P. Lyona jest owocem kilkuletnich studiów na uniwersytetach amerykańskich w Kaliformii między innymi u prof. Stanisława Segerta. Jak słusznie zauważył Lyon, chociaż przed 90-ciu laty wydano teksty ewangelii starosyryjskich (versio curetoniana i sinaitica), to nie przeprowadzono studiów porównawczych między podstawowym tekstem Peszitty a versio curetoniana i sinaitica. Rozprawa Loyna wychodzi naprzeciw temu postulatowi, kiedy stawia sobie za cel przebadanie języka i metody przekładu stosowanych w versio curetoniana, sinaitica, Diatessaronie i Peszitcie. 
Podstawową część rozprawy stanowi dziewięć rozdziałów.

W I rozdziale (s. 3-8) autor omawia cel i metodę pracy. W II rozdziale (s. 920) - literaturę przedmiotu, a więc wydania tekstów źródłowych i dzieł, z których będzie korzystał. W III rozdziale (s. 21-40) autor zajmuje się sposobami tłumaczenia tekstu greckiego na język syryjski, a wśród nich tłumaczenia tekstu greckiego Historii Kościelnej Euzebiusza na język syryjski. W rozdziałach od IV do VIII (s. 41-153) Loyn analizuje perykopy ewangeliczne w świetle przekładów syryjskich, poświęcając każdej jeden rozdział: Mt 18,1-20; Mk 7, 31-37: 10, 17-25; Łk 16, 19-31; J 3, 1-15.

W rozdziale IX (s. 189-207) Lyon przedstawia wnioski, do których doszedł. Oto niektóre z nich: 1). Tłumacze syryjscy dobrze znali język grecki, a idiomy greckie przekładali podobnymi sobie idiomami syryjskimi i dlatego przekłady różnią się wobec siebie. I chociaż tłumacz syryjski nie jest wierny idiomowi greckiemu co do formy, ale pozostaje wierny co do treści. 2). Versio curetoniana posiada duży wpływ Diatessaronu. 3). Versio curetoniana jest młodszym tekstem niż versio sinaitica. 4). Jeżeli versio curetoniana nie zgadza się z versio sinaitica, to należy brać pod uwagę lekcję Diatessaronu. 5). Gramatyczne, ortograficzne i leksykalne anomalie, jakie zachodzą w tekstach ewangelicznych, są zgodne z dialektem Edessy. 6). Tekst Peszitty zachowuje starsze tradycje. 7). Niektóre warianty w Diatessaronie nie bazują na kanonicznych tekstach greckich. 8). Język versio sinaitica jest starszy od cytatów znajdujących się w Diatessaronie.

Na koniec autor zestawia indeksy cytatów biblijnych (s. 219-226), greckich słów (s. 227), indeks nazw własnych (s. 229-231), indeks słów syryjskich (s. 233235). Niniejsza praca zapowiada nowy kierunek w studiach biblijnych, a mianowicie komparatystykę wielu zachowanych wersji syryjskich Nowego Testamentu $\mathrm{z}$ oryginałem greckim.

Ks. Jerzy Woźniak CM - Kraków

\section{T. BAARDA, Essays on the Diatessaron. Contributions to the Biblical Exe- gesis and Theology 11, Kampen 1994, Kok Pharos, ss. 320.}

Przedstawiona książka stanowi zbiór piętnastu artykułów profesora Free University w Amsterdamie T. Baardy, który od 40 lat zajmuje się problematyką Diatessaronu. Teksty Diatessaronu zachowały się w wielu językach i dlatego ta dyscyplina wiedzy wymaga żmudnego i długoletniego przygotowania. Prof. Baarda zajmował się tekstami Diatessaronu w języku arabskim, armeńskim, koptyjskim, syryjskim, greckim, łacińskim, staroholenderskim i starosaksońskim. A oto tytuły niektórych zamieszczonych w tej publikacji artykułów: Diatessaron Tacjana i jego wplyw na wspótczesne przekłady; Ucieczka Jezusa ( $ヒ k$ 4, 29-30) a syryjski Diatessaron; Jezus i Maria (J 20, 16f) według II Listu 